\title{
Multidisciplinary approach of early breast cancer: The biology applied to radiation oncology
}

\author{
Céline Bourgier ${ }^{1 *}$, Mahmut Ozsahin ${ }^{2}$, David Azria ${ }^{3}$
}

\begin{abstract}
Early breast cancer treatment is based on a multimodality approach with the application of clinical and histological prognostic factors to determine locoregional and systemic treatments. The entire scientific community is strongly involved in the management of this disease: radiologists for screening and early diagnosis, gynecologists, surgical oncologists and radiation oncologists for locoregional treatment, pathologists and biologists for personalized characterization, genetic counselors for BRCA mutation history and medical oncologists for systemic therapies.

Recently, new biological tools have established various prognostic subsets of breast cancer and developed predictive markers for miscellaneous treatments.

The aim of this article is to highlight the contribution of biological tools in the locoregional management of early breast cancer.
\end{abstract}

\section{Introduction}

Breast cancer is the most common female cancer in France with increasing incidence over the last two decades and with decreasing mortality [1]. Systematic screening can detects early breast cancers that are potentially curable. All physicians are implicated in the management of early breast cancer: radiologists for screening and diagnosis; gynecologists, breast surgeons, and radiation oncologists for locoregional treatment; pathologists and biologists for individualized tumor characterization; genetic counselors for BRCA mutation history and medical oncologists for systemic therapies.

Recently, biological tools have identified different prognostic subsets of breast cancers, and may predict treatment efficacy [2-8].

This review highlights the contribution of biological tools in a multidisciplinary approach, especially in locoregional treatment of early breast cancers.

\section{Biological tools}

The advent of biological tumor analysis has generated information to classify prognostic features of breast cancer, and to assess treatment efficacy. Recently, several classifications were identified defining the genomic tumor characterization which include: (i) «intrinsic gene

\footnotetext{
* Correspondence: bourgier@igr.fr

'Département d'Oncologie Radiothérapie, Unité fonctionnelle de Sénologie, Institut Gustave Roussy, Villejuif, France
}

signature» [2,3], (ii) tumor proliferation or invasion [4-6], and (iii) tumor aggressiveness « wound signature; invasive gene signature » $[7,8]$. At least three molecular sets have therefore been suggested for breast cancer outcomes: luminal (positive hormonal receptors - HR), triple negative (negative HR/ negative Her2), and Her2 overexpression phenotypes [2-4]. Other biological tools have been developed to identify and classify those genes implied in tumor progression and treatment response, such as tissue micro arrays or comparative genomic hybridization (CGH)-arrays. Furthermore, these tools enable the detection of gene amplification or deletion that can be targeted by new systemic therapies [9].

\section{Differential diagnosis between benign and malignant breast lesions: contribution of biological tools}

Recently, a new molecular classification based on differential expression of genes and exons has identified and generated a molecular classifier for breast cancer diagnosis through differentially expressed exons in malignant and benign breast lesions (accuracy 100\% [IC95\%: 96-100], sensitivity 100\% [IC95\%: 83-100\%], and specificity 100\% [IC95\%: 95-100] [10]. This molecular signature for breast cancer diagnosis with fine-needle aspiration (FNA) is a promising biological tool owing to its safer and quicker procedure [10,11]. The FNA procedure has substantial advantages over core needle biopsy 
(CNB) even though the current guidelines recommend $\mathrm{CNB}$ for diagnosis of ACR grade 4 and 5 lesions and for assessment of tissue and molecular signature. First, FNA is a rapid and cost-effective tool for breast cancer diagnosis in a one-stop multidisciplinary breast clinic [12]. Moreover, FNA samples are more enriched in cancer cells than CNB samples and thus, provide transcriptional profiles of purer representation of the tumor-cell population $[10,13,14]$. In contrast, the main advantage of CNB compared to FNA is the ability to describe tumor architecture but it is more expensive and timeconsuming [15].

\section{Breast cancer chemotherapy and the contribution of biological tools}

The administration of systemic therapies is driven by the assessment of clinical and/or pathological features such as tumor size, nodal involvement, positive or negative hormonal receptors, and Her2 overexpression. However, none of these classical prognostic factors is able to predict the response to treatment of breast cancers. The advent of genomic technologies enables the improvement of prognostic classification and accurate prediction of benefit from systemic therapies for individual patients. The recent review of Di Leo et al. [16] analyzed and detailed all these biological tools and their clinical application, particularly in some ongoing clinical trials.

\section{The contribution of biology and endocrine therapies}

Patients with hormonal receptor-positive breast cancers receive endocrine therapy given over five consecutive years, with either tamoxifen (TAM) in premenopausal women, or aromatase inhibitors (AI) or sequential endocrine therapy in postmenopausal women [17]. To determine which endocrine therapy would benefit a selected patient population is not feasible in daily practice. In this context, biological tools may identify patients in whom AI or TAM as initial endocrine therapy would be of benefit. Recently, Viale et al. have assessed the prognostic and predictive value of $\mathrm{Ki}-67$ labeling index in the Breast International Group (BIG) trial 1-98. A high Ki-67 labeling index level was correlated to a worse disease-free survival (DFS), and patients treated by AI had an enhanced DFS compared to patients treated by TAM. The Ki-67 labeling index level could therefore identify a subgroup of patients who would benefit from initial AI endocrine therapy [18].

\section{Contribution of biology in adjuvant radiotherapy of early breast cancer}

Biological technologies have been largely developed for classifying breast cancers after systemic therapies, and for predicting the efficacy of systemic therapies, whereas biological contribution in the field of locoregional treatment is less developed. Biological applications are warranted to optimize local control for breast cancer patients at high risk of local relapse. Furthermore, these biological tools would identify patients at high risk of late radiation-induced toxicity.

Biological tools: To determine breast cancer patients at high risk of local relapse

The current locoregional management of early breast cancer consists of breast conserving surgery (i.e., lumpectomy and sentinel node biopsy or axillary dissection) followed by whole-breast irradiation (WBI, 50 Gy in 25 fractions over 5 weeks) and then a boost of 10-16 Gy to the tumor bed. WBI significantly reduces local relapse by a factor of two with an absolute gain in local relapse rate of $20 \%$ at 15 years, corresponding to a survival benefit of 5\% [19]. The boost to the tumor bed contributes to a decrease in the local relapse risk of $50 \%$ whatever the patients' age [20-22].

While adjuvant radiotherapy plays a crucial part in the locoregional management of early breast cancer, local relapse still occurs. These local relapses are an independent factor for distant metastatic relapse [23] and for specific cancer mortality [24]. A number of clinical and histological parameters are usually described as prognostic factors for locoregional relapse such as young age, positive or close margins, extensive DCIS [25-28], high tumor grade, presence of vascular embolus and/or lymphovascular invasion (LVI), and tumor size [29-31]. However, none of these parameters are able to predict which patients are at high risk of locoregional relapse. Recently, a computer-based tool "IBTR !" attempted to predict local relapse in women with invasive breast cancer after breast conserving surgery. This nomogram is only valid for patients presenting low risk of local recurrence $[32,33]$. As clinical, histological, and computerbased tools are not sufficient to predict local relapse, prognostic and predictive biological factors are needed. A tissue-micro-array has been built, based on an "intrinsic gene signature" showing that Her2 overexpression and basal-like breast cancer subtypes were prognostic factors for local relapse [34]. Other genomic classifications could be used to determine the risk of local relapse after breast conserving surgery, such as "wound signature" [35].

A history of BRCA1/2 mutation is related to a higher lifetime risk of developing breast cancer and breast conserving treatment remains debatable in this patient population owing to the residual presence of breast tissue which still contains all remaining cells carrying the same deleterious mutations. The BRCA $1 / 2$ mutation is not yet a targeted tool to determine a population of breast cancer at high risk of local relapse. The molecular pathway involved in DNA repair, particularly the role of 
BRCA $1 / 2$ proteins, would suggest a profile of tumor resistance to ionizing radiation (IR) in case of BRCA1/2 mutation, due to underlying in vitro effects. An incorrect repair of DNA double-strand breaks after IR, due to BRCA1/2 mutation, could lead to the development of new primary breast cancer. On the other hand, the in vitro effects of IR on BRCA $1 / 2$ cell lines showed an increased radiosensitivity [36,37], partially related to the loss of bcl-2 expression after IR, leading to an increased radiation-induced apoptosis [38]. Clinical data suggest that BRCA1/2 carriers have a similar local and overall outcome to non-carriers whatever radical or conservative local treatment has been performed $[39,40]$.

\section{Biological tools: a need for combined therapies}

Breast cancer cell lines that overexpressed Her2 oncoprotein are known to be resistant to IR. When trastuzumab was combined with IR, an enhancement of in vitro and in vivo tumor radiosensitization was observed, through DNA repair inhibition and through an increased tumor cell death $[41,42]$. Recently, the addition of trastuzumab to radiotherapy has been shown to be an effective radiosensitizer in patients with Her2 overexpression, with chemotherapy-refractory disease, locally-advanced or recurrent breast cancer in a phase II trial. Although these breast cancers were initially considered to be inoperable, breast surgery could be performed in $58 \%$ of patients with a substantial pathologic response (complete response or microscopic residual disease) in $43 \%$ of patients [43].

\section{Biological tools: To a personalized radiosensitivity of} normal tissues

Different parameters could be involved in the development of late radiation-induced toxicity, such as genetic factors (DNA repair deficiency) or epigenetic factors (obesity, vascular, or collagen diseases...). Other issues could also be involved in radiation-induced toxicities such as radiotherapy parameters (total dose, dose per fraction, irradiated target and normal tissue volumes), history of surgery within irradiated fields, and the combination of either chemotherapy or endocrine therapy with radiation therapy.

Recently, a nomogram was built to predict the risk of fibrosis after breast-conserving therapy [44]. This computer-based tool allocated points according to various factors such as age, postoperative hematoma, breast edema, the use (concomitant or not) of tamoxifen and/ or chemotherapy, radiotherapy parameters (photon energy [6 MV or more], electron or photon boost, energy of electron boost in case of electron use, maximal total dose). The main limitation for daily use of this nomogram is that this computer-based tool cannot identify a population at high risk of severe late radiation-induced toxicities. Indeed, when usual radiotherapy parameters were considered, i.e., 6-MV photons, a total dose of 66 Gy and photon beam boost, the nomogram predicts an over-risk of fibrosis of $50 \%$ at 10 years. This over-risk is larger than observed fibrosis after breast conserving therapy.

Biological predictive factors are warranted to identify the individual risk of development of severe late toxicity. A lymphocyte apoptosis assay has been developed as a rapid tool for characterization of normal tissue radiosensitivity, particularly due to the ease of blood collection in a standardized, patient-friendly manner [45-47]. Severe late radiation-induced toxicities (grade 2 or more) were correlated to a low rate of radiation-induced CD8 T-lymphocyte apoptosis $(\leq 16 \%)[48,49]$. In addition, patients with severe late effects possessed four or more SNPs (Single Nucleotide Polymorphisms) in candidate genes (ATM, TGFB1, XRCC1, XRCC3, SOD2, and RAD21) [48].

\section{Conclusion}

Biological tools can play a part in each step of the management of early breast cancer from diagnosis to treatment; i.e., surgery, adjuvant radiotherapy, and systemic therapies. Currently used biological tools for prognostic classification or for predicting systemic treatment efficacy, could be applied for locoregional treatments to predict antitumor efficacy. In addition, radiation oncologists have developed new tools focusing on normal tissue radiosensitivity that may be adapted to systemic therapies in the near future. Dedicated prospective studies are urgently warranted in this setting.

\section{Conflict of interests}

The authors declare that they have no competing interests.

\section{Author details}

'Département d'Oncologie Radiothérapie, Unité fonctionnelle de Sénologie, Institut Gustave Roussy, Villejuif, France. ${ }^{2}$ Service de Radio-Oncologie, Centre Hospitalier Universitaire Vaudois, Lausanne, Switzerland. ${ }^{3}$ Département d'Oncologie Radiothérapie, Université Montpellier I, CRLC Val d'Aurelle, Montpellier, France.

\section{Authors' contributions}

$\mathrm{CB}, \mathrm{MH}$ and $\mathrm{DA}$ : conception, design. All the listed authors have been involved in drafting or in revising the manuscript. All authors read and approved the final manuscript.

Received: 9 November 2009

Accepted: 14 January 2010 Published: 14 January 2010

\section{References}

1. Belot A, Grosclaude P, Bossard N, Jougla E, Benhamou E, Delafosse $P$, Guizard AV, Molinie F, Danzon A, Bara S, Bouvier AM, Tretarre B, BinderFoucard F, Colonna M, Daubisse L, Hedelin G, Launoy G, Le Stang N, Maynadie M, Monnereau A, Troussard X, Faivre J, Collignon A, Janoray I, Arveux P, Buemi A, Raverdy N, Schvartz C, Bovet M, Cherie-Challine L, Esteve J, Remontet L, Velten M: Cancer incidence and mortality in France over the period 1980-2005. Rev Epidemiol Sante Publique 2008, 56:159-75. 
2. Perou CM, Sorlie T, Eisen MB, Rijn van de M, Jeffrey SS, Rees CA, Pollack JR, Ross DT, Johnsen H, Akslen LA, Fluge O, Pergamenschikov A, Williams C, Zhu SX, Lonning PE, Borresen-Dale AL, Brown PO, Botstein D: Molecular portraits of human breast tumours. Nature 2000, 406:747-52

3. Sorlie T, Perou CM, Tibshirani R, Aas T, Geisler S, Johnsen H, Hastie T, Eisen MB, Rijn van de M, Jeffrey SS, Thorsen T, Quist H, Matese JC, Brown PO, Botstein D, Eystein Lonning P, Borresen-Dale AL: Gene expression patterns of breast carcinomas distinguish tumor subclasses with clinical implications. Proc Natl Acad Sci USA 2001, 98:10869-74.

4. van 't Veer $L$, Dai H, Vijver van de MJ, He YD, Hart AA, Mao M, Peterse HL, Kooy van der K, Marton MJ, Witteveen AT, Schreiber GJ, Kerkhoven RM, Roberts C, Linsley PS, Bernards R, Friend SH: Gene expression profiling predicts clinical outcome of breast cancer. Nature 2002, 415:530-6.

5. Paik S, Shak S, Tang G, Kim C, Baker J, Cronin M, Baehner FL, Walker MG Watson D, Park T, Hiller W, Fisher ER, Wickerham DL, Bryant J, Wolmark N: A multigene assay to predict recurrence of tamoxifen-treated, nodenegative breast cancer. N Engl J Med 2004, 351:2817-26.

6. Wang Y, Klijn JG, Zhang Y, Sieuwerts AM, Look MP, Yang F, Talantov D, Timmermans M, Meijer-van Gelder ME, Yu J, Jatkoe T, Berns EM, Atkins D, Foekens JA: Gene-expression profiles to predict distant metastasis of lymph-node-negative primary breast cancer. Lancet 2005, 365:671-9.

7. Chang HY, Nuyten DS, Sneddon JB, Hastie T, Tibshirani R, Sorlie T, Dai H, He YD, van't Veer LJ, Bartelink H, Rijn van de M, Brown PO, Vijver van de MJ: Robustness, scalability, and integration of a wound-response gene expression signature in predicting breast cancer survival. Proc Natl Acad Sci USA 2005, 102:3738-43.

8. Liu R, Wang X, Chen GY, Dalerba P, Gurney A, Hoey T, Sherlock G, Lewicki J, Shedden K, Clarke MF: The prognostic role of a gene signature from tumorigenic breast-cancer cells. N Engl J Med 2007, 356:217-26.

9. van Beers EH, Nederlof PM: Array-CGH and breast cancer. Breast Cancer Res 2006, 8:210.

10. Andre F, Michiels S, Dessen P, Scott V, Suciu V, Uzan C, Lazar V, Lacroix L, Vassal G, Spielmann M, Vielh $P$, Delaloge S: Exonic expression profiling of breast cancer and benign lesions: a retrospective analysis. Lancet Oncol 2009, 10:381-90

11. Bueno-de-Mesquita JM, van Harten WH, Retel VP, van't Veer $L$, van Dam FS, Karsenberg K, Douma KF, van Tinteren H, Peterse JL, Wesseling J, Wu TS, Atsma D, Rutgers EJ, Brink G, Floore AN, Glas AM, Roumen RM, Bellot FE, van Krimpen C, Rodenhuis S, Vijver van de MJ, Linn SC: Use of 70-gene signature to predict prognosis of patients with node-negative breast cancer: a prospective community-based feasibility study (RASTER). Lancet Oncol 2007, 8:1079-87.

12. Delaloge S, Noel E, Andre F, Benhamou E, Larue C, Balleyguier C, Vielh P, de Pouvourville G: Medico-economic evaluation of the rapid diagnosis of breast lesions using fine-needle aspiration in a one stop breast clinic (Abstr. 3040). Breast Cancer Research and Treatment 2007, 106(Supplement 1).

13. Symmans WF, Ayers M, Clark EA, Stec J, Hess KR, Sneige N, Buchholz TA, Krishnamurthy S, Ibrahim NK, Buzdar AU, Theriault RL, Rosales MF, Thomas ES, Gwyn KM, Green MC, Syed AR, Hortobagyi GN, Pusztai L: Total RNA yield and microarray gene expression profiles from fine-needle aspiration biopsy and core-needle biopsy samples of breast carcinoma. Cancer 2003, 97:2960-71.

14. Uzan C, Andre F, Scott V, Laurent I, Azria E, Suciu V, Balleyguier C, Lacroix L, Delaloge $S$, Vielh P: Fine-needle aspiration for nucleic acid-ased molecular analyses in breast cancer. Cancer Cytopathol 2009, 117:32-9.

15. Meunier M, Clough K: Fine needle aspiration cytology versus percutaneous biopsy of nonpalpable breast lesions. Eur J Radiol 2002, 42:10-6.

16. Oakman C, Bessi S, Zafarana E, Galardi F, Biganzoli L, Di Leo A: Recent advances in systemic therapy: new diagnostics and biological predictors of outcome in early breast cancer. Breast Cancer Res 2009, 11:205.

17. Goldhirsch A, Wood WC, Gelber RD, Coates AS, Thurlimann B, Senn HJ: Progress and promise: highlights of the international expert consensus on the primary therapy of early breast cancer 2007. Ann Oncol 2007. 18:1133-44.

18. Viale G, Giobbie-Hurder A, Regan MM, Coates AS, Mastropasqua MG, Dell'Orto P, Maiorano E, MacGrogan G, Braye SG, Ohlschlegel C, Neven P, Orosz Z, Olszewski WP, Knox F, Thurlimann B, Price KN, CastiglioneGertsch M, Gelber RD, Gusterson BA, Goldhirsch A: Prognostic and predictive value of centrally reviewed $\mathrm{Ki}-67$ labeling index in postmenopausal women with endocrine-responsive breast cancer: results from Breast International Group Trial 1-98 comparing adjuvant tamoxifen with letrozole. J Clin Oncol 2008, 26:5569-75.

19. Clarke M, Collins R, Darby S, Davies C, Elphinstone P, Evans E, Godwin J, Gray R, Hicks C, James S, MacKinnon E, McGale P, McHugh T, Peto R, Taylor C, Wang YM: Effects of radiotherapy and of differences in the extent of surgery for early breast cancer on local recurrence and 15-year survival: an overview of the randomised trials. Lancet 2005, 366:2087-106.

20. Bartelink $H$, Horiot JC, Poortmans P, Struikmans H, Bogaert Van den W, Barillot I, Fourquet A, Borger J, Jager J, Hoogenraad W, Collette L, Pierart M: Recurrence rates after treatment of breast cancer with standard radiotherapy with or without additional radiation. $N$ Engl J Med 2001, 345:1378-87.

21. Dilhuydy JM, Bussieres E, Romestaing P: [Radiotherapy of the breast and chest wall: treatment volume]. Cancer Radiother 2001, 5:550-9.

22. Fernando IN, Ford HT, Powles TJ, Ashley S, Glees JP, Torr M, Grafton D, Harmer $C L$ : Factors affecting acute skin toxicity in patients having breast irradiation after conservative surgery: a prospective study of treatment practice at the Royal Marsden Hospital. Clin Oncol (R Coll Radiol) 1996, 8:226-33.

23. Azria D, Rat F, Huguet H, Lemanski C, Llacer Moscardo C, Kerr C, Hay M, Dubois JB: Postmastectomy Radiotherapy in Intermediate-risk Patients: Long Term Carcinologic and Quality of Life Results of the Montpellier Cancer Center. Int J Radiat Oncol Biol Phys 2009, 75.

24. Vicini FA, Kestin L, Huang R, Martinez A: Does local recurrence affect the rate of distant metastases and survival in patients with early-stage breast carcinoma treated with breast-conserving therapy?. Cancer 2003, 97:910-9.

25. Elkhuizen PH, Vijver van de MJ, Hermans J, Zonderland HM, Velde van de CJ, Leer JW: Local recurrence after breast-conserving therapy for invasive breast cancer: high incidence in young patients and association with poor survival. Int J Radiat Oncol Biol Phys 1998, 40:859-67.

26. Arriagada R, Le MG, Contesso G, Guinebretiere JM, Rochard F, Spielmann M: Predictive factors for local recurrence in 2006 patients with surgically resected small breast cancer. Ann Oncol 2002, 13:1404-13.

27. Arriagada R, Le MG, Guinebretiere JM, Dunant A, Rochard F, Tursz T: Late local recurrences in a randomised trial comparing conservative treatment with total mastectomy in early breast cancer patients. Ann Oncol 2003, 14:1617-22.

28. Huston $\mathrm{TL}$, Simmons RM: Locally recurrent breast cancer after conservation therapy. Am J Surg 2005, 189:229-35.

29. Clarke DH, Le MG, Sarrazin D, Lacombe MJ, Fontaine F, Travagli JP, MayLevin F, Contesso G, Arriagada R: Analysis of local-regional relapses in patients with early breast cancers treated by excision and radiotherapy: experience of the Institut Gustave-Roussy. Int J Radiat Oncol Biol Phys 1985, 11:137-45.

30. Fisher B, Anderson S, Fisher ER, Redmond C, Wickerham DL, Wolmark N, Mamounas EP, Deutsch M, Margolese R: Significance of ipsilateral breast tumour recurrence after lumpectomy. Lancet 1991, 338:327-31.

31. Locker AP, Ellis IO, Morgan DA, Elston CW, Mitchell A, Blamey RW: Factors influencing local recurrence after excision and radiotherapy for primary breast cancer. Br J Surg 1989, 76:890-4.

32. Truong PT, Lesperance ML, Sanghani M, Jones $H$, Tighouart $H$, Wazer $D$, Olivotto IA: Independent Validation of IBTR! A Computer-based Tool to Predict Ipsilateral Breast Recurrence in Women with Invasive Breast Cancer Treated with Breast Conserving Surgery. Int J Radiat Oncol Biol Phys 2008, 72:\#203.

33. Sanghani M, Raad RA, Niemierko A, Taghian A, Wazer D: Validation of a Web-based Predictive Nomogram for Ipsilateral Breast Tumor Recurrence after Breast Conserving Therapy. Int J Radiat Oncol Biol Phys 2008, 72:S91.

34. Nguyen PL, Taghian AG, Katz MS, Niemierko A, Abi Raad RF, Boon WL, Bellon JR, Wong JS, Smith BL, Harris JR: Breast cancer subtype approximated by estrogen receptor, progesterone receptor, and HER-2 is associated with local and distant recurrence after breast-conserving therapy. J Clin Oncol 2008, 26:2373-8.

35. Nuyten DS, Kreike B, Hart AA, Chi JT, Sneddon JB, Wessels LF, Peterse H, Bartelink H, Brown PO, Chang HY, Vijver Van de MJ: Predicting a local recurrence after breast-conserving therapy by gene expression profiling. Breast Cancer Res 2006, 8:R62 
36. Gowen LC, Avrutskaya AV, Latour AM, Koller BH, Leadon SA: BRCA1 required for transcription-coupled repair of oxidative DNA damage. Science 1998, 281:1009-12.

37. Hanawalt PC: Transcription-coupled repair and human disease. Science 1994, 266:1957-8.

38. Freneaux P, Stoppa-Lyonnet D, Mouret E, Kambouchner M, Nicolas A, Zafrani B, Vincent-Salomon A, Fourquet A, Magdelenat H, Sastre-Garau X: Low expression of bcl-2 in Brca1-associated breast cancers. $\mathrm{Br} J$ Cancer 2000, 83:1318-22.

39. Pierce L, Levin AM, Rebbeck TR, Ben-David MA, Friedman E, Solin LJ, Harris EE, Gaffney DK, Haffty BG, Dawson LA, Narod SA, Olivotto IA, Eisen A, Whelan TJ, Olopade OI, Isaacs C, Merajver SD, Wong JS, Garber JE, Weber BL: Ten-year multi-institutional results of breast-conserving surgery and radiotherapy in BRCA1/2-associated stage $1 / / \mathrm{l}$ breast cancer. $J$ Clin Oncol 2006, 24:2437-43.

40. Kirova YM, Stoppa-Lyonnet D, Savignoni A, Sigal-Zafrani B, Fabre N, Fourquet A: Risk of breast cancer recurrence and contralateral breast cancer in relation to BRCA1 and BRCA2 mutation status following breast-conserving surgery and radiotherapy. Eur I Cancer 2005, 41:2304-11.

41. Liang K, Lu Y, Jin W, Ang KK, Milas L, Fan Z: Sensitization of breast cancer cells to radiation by trastuzumab. Mol Cancer Ther 2003, 2:1113-20.

42. Pietras RJ, Poen JC, Gallardo D, Wongvipat PN, Lee HJ, Slamon DJ: Monoclonal antibody to HER-2/neureceptor modulates repair of radiation-induced DNA damage and enhances radiosensitivity of human breast cancer cells overexpressing this oncogene. Cancer Res 1999, 59:1347-55.

43. Horton JK, Halle J, Ferraro M, Carey L, Moore DT, Ollila D, Sartor Cl: Radiosensitization of Chemotherapy-Refractory, Locally Advanced or Locally Recurrent Breast Cancer with Trastuzumab: A Phase II Trial. Int $J$ Radiat Oncol Biol Phys 2009.

44. Collette S, Collette L, Budiharto T, Horiot JC, Poortmans PM, Struikmans H, Bogaert Van den W, Fourquet A, Jager JJ, Hoogenraad W, Mueller RP, Kurtz J, Morgan DA, Dubois JB, Salamon E, Mirimanoff R, Bolla M, Hulst Van der M, Warlam-Rodenhuis CC, Bartelink H: Predictors of the risk of fibrosis at 10 years after breast conserving therapy for early breast cancer: a study based on the EORTC Trial 22881-10882 'boost versus no boost'. Eur $J$ Cancer 2008, 44:2587-99.

45. Ozsahin M, Ozsahin H, Shi Y, Larsson B, Wurgler FE, Crompton NE: Rapid assay of intrinsic radiosensitivity based on apoptosis in human CD4 and CD8 T-lymphocytes. Int I Radiat Oncol Biol Phys 1997, 38:429-40.

46. Crompton NE, Shi YQ, Emery GC, Wisser L, Blattmann H, Maier A, Li L, Schindler D, Ozsahin H, Ozsahin M: Sources of variation in patient response to radiation treatment. Int J Radiat Oncol Biol Phys 2001, 49:547-54.

47. Slonina D, Gasinska A: Intrinsic radiosensitivity of healthy donors and cancer patients as determined by the lymphocyte micronucleus assay. Int J Radiat Biol 1997, 72:693-701.

48. Azria D, Ozsahin M, Kramar A, Peters S, Atencio DP, Crompton NE, Mornex F, Pelegrin A, Dubois JB, Mirimanoff RO, Rosenstein BS: Single nucleotide polymorphisms, apoptosis, and the development of severe late adverse effects after radiotherapy. Clin Cancer Res 2008, 14:6284-8.

49. Ozsahin M, Crompton NE, Gourgou S, Kramar A, Li L, Shi Y, Sozzi WJ, Zouhair A, Mirimanoff RO, Azria D: CD4 and CD8 T-lymphocyte apoptosis can predict radiation-induced late toxicity: a prospective study in 399 patients. Clin Cancer Res 2005, 11:7426-33.

doi:10.1186/1748-717X-5-2

Cite this article as: Bourgier et al:: Multidisciplinary approach of early breast cancer: The biology applied to radiation oncology. Radiation Oncology 2010 5:2.

Publish with BioMed Central and every scientist can read your work free of charge

"BioMed Central will be the most significant development for disseminating the results of biomedical research in our lifetime. "

Sir Paul Nurse, Cancer Research UK

Your research papers will be:

- available free of charge to the entire biomedical community

- peer reviewed and published immediately upon acceptance

- cited in PubMed and archived on PubMed Central

- yours - you keep the copyright 